\begin{tabular}{|c|c|c|c|c|}
\hline JURNAL & \multirow{2}{*}{ VOLUME 2 } & \multirow{2}{*}{ NOMOR 2 } & HALAMAN 86-92 & $\begin{array}{c}\text { ISSN 2655-8823 }(p) \\
\text { ISSN 2656-1786 }(e)\end{array}$ \\
KOLABORASI RESOLUSI KONFLIK & H
\end{tabular}

\title{
IDENTITAS DALAM KONFLIK DI KALIMANTAN BARAT (SEBUAH PEMETAAN KONFLIK)
}

\author{
Faraz Sumaya \\ Program Studi Magister Sosiologi FISIP Universitas Padjadjaran \\ E-mail: farazsumaya23@gmail.com
}

\begin{abstract}
Abstrak
Konflik yang terjadi di Kalimantan Barat cukup banyak terutama konflik yang berbasis identitas etnis. Artikel ini mencoba untuk menggambarkan pemetaan potensi konflik yang terjadi di Kalimantan Barat dengan menggunakan Segitiga SPK (Sikap, Perilaku, Konteks). Pemetaan dengan Segitiga SPK dianggap bisa menggambarkan potensi konflik yang bernuansa etnis dengan cara mengidentifikasi prasangka-prasangka yang berkembang antar etnis yang berkonflik. Segitiga SPK ini bisa menjadi alternatif pemetaan konflik yang telah terjadi, ataupun sebagai prakiraan potensi konflik yang akan terjadi dimasa yang akan datang.
\end{abstract}

Kata Kunci: Konflik, Segitiga SPK, identitas.

\section{PENDAHULUAN}

Kalimantan Barat menjadi salah satu daerah yang memiliki jumlah konflik cukup banyak. Menurut Kristianus (2011) setidaknya ada 17 konflik yang terjadi dalam rentang tahun 1966-2008. Dari 17 konflik tersebut didominasi oleh konflik antar etnis. Konflik antar etnis ini diisi dengan konflik etnis Dayak-etnis Madura, Melayu-Madura, Melayu-Tionghoa. Akan tetapi kemudian konflik antar etnis mulai bergeser dalam beberapa tahun belakangan menjadi konflik antara salah satu etnis dengan ormas keagamaan.

Menurut Alqadrie (2000), siklus konflik Kalimantan Barat akan terus berlangsung setiap 30 tahun sekali (Alqadrie, 2008). Fisher (2000) menyatakan bahwa penyebab konflik dikarenakan masing-masing merasa identitas mereka terancam. Hal ini kemudian melahirkan prasangka, steriotipe, dan diskriminasi sebagai efek negatif yang mana jika tidak segera diidentifikasi dan diselesaikan, maka akan berpotensi besar terjadinya konflik dan kekerasan (Fisher, 2000). Untuk mengidentifikasi prasangka-prasangka antar pihak yang berkonflik atau pernah berkonflik, maka bisa digunakan segitiga SPK (Sikap Perilaku Konteks). Penggunaan ini merupakan sebuah upaya untuk memetakan konflik atau bisa juga menjadi alat perkiraan terjadinya konflik dimasa yang akan datang, terutama konflik antara Etnis Dayak-Madura yang mana konflik antar kedua enis ini menjadi konflik terbanyak yang pernah terjadi di Kalimantan Barat. Untuk itu artikel ini mencoba menggunakan segitiga SPK dalam gambaran konflik yang terjadi di Kalimantan Barat.

\section{METODE PENELITIAN}

Penelitian ini menggunakan jenis pendekatan kualitatif deskriptif yang mana untuk mendapatkan data dalam penelitian ini penulis menggunakan studi literatur. Creswell (2012) menyebutkan data penelitian kualitatif dapat berupa lisan dan tulisan. Data dalam penelitian ini didapatkan melalui penelusuran tulisantulisan ilmiah seperti jurnal dan buku yang terkait dengan tema penelitian serta sumber-sumber tulisan dari media yang kredibel.

\section{HASIL DAN PEMBAHASAN}

Kristianus (2011) mencoba mengurutkan peristiwa konflik yang pernah terjadi di Kalimantan Barat periode 1966-2008. Berikut adalah tabel konflik di Kalimantan Barat. 


\begin{tabular}{|c|c|c|c|c|}
\hline JURNAL & \multirow{2}{*}{ VOLUME 2} & NOMOR 2 & HALAMAN 86-92 & $\begin{array}{l}\text { ISSN 2655-8823 }(p) \\
\text { ISSN 2656-1786 }(e)\end{array}$ \\
KOLABORASI RESOLUSI KONFLIK & &
\end{tabular}

Tabel 1. Waktu, Lokasi dan Etnis yang Pernah Berkonflik di Kalimantan Barat

\begin{tabular}{|c|c|c|c|}
\hline No. & Waktu & Lokasi & Keterangan \\
\hline 1. & $1966-67$ & $\begin{array}{l}\text { Kabupaten } \\
\text { Sambas,Pontianak, } \\
\text { Sanggau, Sintang, } \\
\text { Ketapang }\end{array}$ & $\begin{array}{l}\text { Konflik etnik Dayak dengan Cina. Seluruh etnik } \\
\text { Cina diusir dari kampung-kampung pedalaman } \\
\text { Kalimantan Barat. Konflik ini didukung oleh } \\
\text { Militer yang dikaitkan dengan penumpasan PKI } \\
\text { dan PGRS-Paraku. Pada masa ini terjadi } \\
\text { penggulingan Gubernur Oevang Oerai dan } 4 \text { orang } \\
\text { Bupati dari etnik Dayak }\end{array}$ \\
\hline 2. & 1968 & $\begin{array}{l}\text { Anjungan, } \\
\text { Kabupaten } \\
\text { Pontianak }\end{array}$ & $\begin{array}{l}\text { Konflik enik Dayak dengan Madura, Konflik } \\
\text { dipicu oleh pembunuhan terhadap Sani (Camat } \\
\text { Sungai Pinyuh yang orang Dayak Kanayatn) oleh } \\
\text { Sukri warga Madura. Pembunuhan ini } \\
\text { dilatarbelakangi oleh penolakan Camat tersebut } \\
\text { untuk melayani pengurusan surat keterangan tanah } \\
\text { pada hari minggu karena Camat itu ingin ke } \\
\text { Gereja. Pada masa ini suasana politik tidak } \\
\text { menentu. }\end{array}$ \\
\hline 3. & 1976 & $\begin{array}{l}\text { Di Sungai pinyuh, } \\
\text { Kabupaten } \\
\text { Pontianak }\end{array}$ & $\begin{array}{l}\text { Konflik etnik Dayak dengan Madura, Konflik } \\
\text { dipacu oleh terbunuhnya seorang Dayak Kanayatn, } \\
\text { yaitu Cangkeh asal Liongkong/Sukaramai yang } \\
\text { dilakukan oleh seorang warga Madura yang } \\
\text { mengambil rumput di tanah milik korban. } \\
\text { Peristiwa ini terjadi sebelum Pemilu tahun } 1977\end{array}$ \\
\hline 4. & 1977 & $\begin{array}{c}\text { Di Singkawang, } \\
\text { kabupaten Sambas }\end{array}$ & $\begin{array}{l}\text { Konflik ini, Dipicu oleh terbunuhnya seorang } \\
\text { Dayak Kanayatn anggota Polri bernama Robert } \\
\text { Lanceng oleh seorang warga Madura. Sebelum } \\
\text { kejadian, korban menegur adik perempuannya agar } \\
\text { jangan pergi keluar rumah malam hari bersama } \\
\text { pemuda Madura tersebut. Peristiwa ini pada tahun } \\
\text { yang sama dengan PEMILU dan sebelum } \\
\text { pemilihan Gubernur }\end{array}$ \\
\hline 5. & 1979 & $\begin{array}{l}\text { Kabupaten } \\
\text { Sambas }\end{array}$ & $\begin{array}{l}\text { Konflik dipicu oleh pertengkaran masalah hutang } \\
\text { yang menyebabkan Sakep (seorang Dayak } \\
\text { Kanayatn) diserang oleh tiga orang Madura. Dua } \\
\text { Dayak Kanayant lainnya hampir terbunuh. Konflik } \\
\text { ini merupakan dampak dari kekecewaan dari etnik } \\
\text { Dayak karena hanya sedikit etnik Dayak yang } \\
\text { duduk di lembaga legislative dan eksekutive. }\end{array}$ \\
\hline 6. & 1982 & $\begin{array}{l}\text { Pak Kucing, } \\
\text { Kabupaten } \\
\text { Sambas }\end{array}$ & $\begin{array}{l}\text { Konflik dipicu oleh pembunuhan terhadap Sidik } \\
\text { seorang warga Dayak Kanayatn oleh Aswandi } \\
\text { seorang warga Madura karena korban menegur } \\
\text { Aswandi yang mengambil rumput disawah }\end{array}$ \\
\hline
\end{tabular}




\begin{tabular}{|c|c|c|c|c|}
\hline JURNAL & \multirow{2}{*}{ VOLUME 2 } & \multirow{2}{*}{ NOMOR 2 } & HALAMAN 86-92 & $\begin{array}{l}\text { ISSN 2655-8823 }(p) \\
\text { ISSN 2656-1786 }(e)\end{array}$ \\
KOLABORASI RESOLUSI KONFLIK & H
\end{tabular}

\begin{tabular}{|c|c|c|c|}
\hline & & & $\begin{array}{l}\text { miliknya tanpa pemberitahuan terlebih dahulu. } \\
\text { Pada tahun ini juga dilaksanakan PEMILU. }\end{array}$ \\
\hline 7. & 1983 & $\begin{array}{l}\text { Sungai Enau, } \\
\text { Kecamatan Sungai } \\
\text { Ambawang, } \\
\text { Kabupaten } \\
\text { Pontianak }\end{array}$ & $\begin{array}{l}\text { Konflik dipicu oleh Dul Arif seorang warga } \\
\text { Madura yang melakukan pembunuhan atas seorang } \\
\text { warga Dayak Kanayatn yang bernama Djaelani } \\
\text { karena masalah tanah. Peristiwa terjadi setelah } \\
\text { PEMILU dan menjelang pemilihan Gubenur }\end{array}$ \\
\hline 8. & 1992 & $\begin{array}{l}\text { Pak Kucing, } \\
\text { Kabupaten } \\
\text { Sambas }\end{array}$ & $\begin{array}{l}\text { Konflik dipicu oleh pemerkosaan terhadap anak } \\
\text { Sidik (yang terbunuh ada tahun 1982) yang } \\
\text { dilakukan oleh seorang warga Madura. Peristiwa } \\
\text { terjadi pada masa yang sama dengan PEMILU. }\end{array}$ \\
\hline 9. & 1993 & $\begin{array}{l}\text { Kotamadya } \\
\text { Pontianak }\end{array}$ & $\begin{array}{l}\text { Konflik massal dipicu oleh perkelahian antar } \\
\text { pemuda Dayak dengan pemuda Madura yang } \\
\text { mengakibatkan perusakan dan pembakaran } \\
\text { terhadap Gereja Paroki Maria Ratu Pencinta } \\
\text { Damai dan Persekolahan Kristen Abdi Agape. } \\
\text { Peristiwa ini terjadi setelah PEMILU dan } \\
\text { menjelang Pemilihan Gubernur. }\end{array}$ \\
\hline 10. & 1994 & $\begin{array}{l}\text { Tubang Titi, } \\
\text { Kabupaten } \\
\text { Ketapang }\end{array}$ & $\begin{array}{l}\text { Konflik dipicu oleh penusukan seorang Dayak } \\
\text { oleh seorang Madura yang sedang bekerja } \\
\text { diproyek pembangunan jalan. Pada masa ini } \\
\text { dilaksanakan pemilihan Bupati Sintang. Calon } \\
\text { Dayak dikalahkan etnik Melayu karena ada } \\
\text { pengkianatan. }\end{array}$ \\
\hline 11 & $\begin{array}{c}28 \text { Des } \\
1996\end{array}$ & $\begin{array}{l}\text { Sanggau Ledo, } \\
\text { Kabupaten } \\
\text { Sambas }\end{array}$ & $\begin{array}{l}\text { Konflik dipicu oleh tertusuknya Yakundus dan } \\
\text { Akim, dua pemuda Dayak Kanayatn di Sanggau } \\
\text { Ledo oleh pemuda Madura, yaitu Bakri dan empat } \\
\text { temannya. Konflik ini terjadi menjelang Pemilu. }\end{array}$ \\
\hline 12. & $\begin{array}{l}15 \text { Jan-28 } \\
\text { Feb } 1997\end{array}$ & $\begin{array}{c}\text { Kabupaten } \\
\text { Sambas, } \\
\text { Kabupaten } \\
\text { Pontianak, } \\
\text { Kabupaten } \\
\text { Sanggau Kapuas, } \\
\text { dan Kotamadya } \\
\text { Pontianak }\end{array}$ & $\begin{array}{l}\text { Konflik Dayak-Madura di daerah kabupaten } \\
\text { Sambas mulai mereda, tetapi kemudian meledak } \\
\text { lagi setelah terjadi penyerangan terhadap kompleks } \\
\text { persekolahan SLTP-SMU Asisi di Siantan. Dalam } \\
\text { peristiwa ini dua perempuan Dayak Jangkang } \\
\text { (Sanggau Kapuas) dan Dayak Menyuke (Landak) } \\
\text { luka-luka. Kemudian, terbunuhnya seorang warga } \\
\text { Dayak Kanayatn asal Tebas-Sambas, yakni } \\
\text { Nyangkot oleh sekelompok warga Madura di } \\
\text { Peniraman. Pada tahun ini dilaksanakan PEMILU, } \\
\text { Pemilihan Bupati Sanggau dan pemilihan } \\
\text { Gubernur. Selain itu keadaan politik Nasional di } \\
\text { Jakarta juga sedang memanas. }\end{array}$ \\
\hline 13 & $\begin{array}{c}17 \text { Jan } \\
1999\end{array}$ & Kab Sambas & $\begin{array}{l}\text { Dikenal sebagai kasus parit Setia, kerusuhan antara } \\
\text { Melayu dan Madura. Peristiwa ini terjadi pada } \\
\text { tahun diadakannya Pemilu } 1999 \text {. }\end{array}$ \\
\hline
\end{tabular}




\begin{tabular}{|c|c|c|c|c|}
\hline JURNAL & \multirow{2}{*}{ VOLUME 2 } & NOMOR 2 & HALAMAN 86-92 & $\begin{array}{l}\text { ISSN 2655-8823 }(p) \\
\text { ISSN 2656-1786 }(e)\end{array}$ \\
\hline
\end{tabular}

\begin{tabular}{|c|c|c|c|}
\hline 14 & $\begin{array}{c}\text { Maret } \\
1999\end{array}$ & $\begin{array}{l}\text { Kabupaten } \\
\text { Sambas, dan } \\
\text { Kotamadya } \\
\text { Pontianak }\end{array}$ & $\begin{array}{l}\text { Berbarengan dengan konflik Melayu Sambas- } \\
\text { Madura, terjadi pembunuhan terhadap Martinus } \\
\text { Amat warga Dayak Kanayatn Samalantan } \\
\text { sehingga mengundang simpati warga (Dayak } \\
\text { Kanayatn) di Samalantan dan Sanggau Ledo untuk } \\
\text { membalas. Pada masa ini juga berlangsung } \\
\text { pemilihan Bupati Pontianak yang rusuh karena } \\
\text { gedung DPRD Mempawah dibakar massa. Di } \\
\text { Bengkayang juga terjadi kekacauan pada pemlihan } \\
\text { Bupati Bengkayang. Yang menarik bahwa Pada } \\
\text { masa ini juga bersamaan dengan pemilihan } \\
\text { anggota MPR yang akan mewakili etnik di } \\
\text { Kalimantan Barat. }\end{array}$ \\
\hline 15 & $\begin{array}{c}\text { Maret } \\
2003\end{array}$ & Sei Duri & $\begin{array}{l}\text { Melayu sambas marah karena pemukiman mereka } \\
\text { di Sei Duri dimasukan ke dalam wilayah } \\
\text { kabupaten Bengkayang yang dipimpin Dayak } \\
\text { Selako. Pada tahun ini juga dilaksanakan } \\
\text { pemilihan Gubenur Kalimantan Barat dan Pemilu.. }\end{array}$ \\
\hline 16 & 2007 & Kota Pontianak & $\begin{array}{l}\text { Melayu rusuh dengan Cina, kasusnya dipicu oleh } \\
\text { tergores mobil seorang etnik Melayu. Paristiwa ini } \\
\text { terjadi setelah Pemilihan Gubernur, calon dari } \\
\text { Melayu Kalah. Selain itu pada Pemilihan } \\
\text { Wali kotaSingkawang, etnik Cina yang menang } \\
\text { sedangkan calon dari Melayu kalah. }\end{array}$ \\
\hline 17 & 2008 & $\begin{array}{c}\text { Kota Singkawang } \\
\text { (Sambas) }\end{array}$ & $\begin{array}{l}\text { Melayu rusuh dengan Cina di Singkawang, dipicu } \\
\text { pembangunan patung Naga. Pada masa ini juga } \\
\text { berlangsung Pemilu } 2009 \text {. }\end{array}$ \\
\hline
\end{tabular}

Sumber: Kristianus (2011)

Jika kita analisis dari berbagai konflik yang terjadi di Kalimantan Barat, semua konflik merupakan konflik yang bernuansa etnisitas. Menurut Haba (2012), kontestasi untuk memperoleh posisi sosial dan hakhak khusus di pemerintahan dan bidangbidang usaha antara orang lokal dan pendatang, berakibat pada meruncingnya hubungan antaretnis. Bahkan isu etnis yang dihubungkan dengan agama, penguasaan sumber daya alam, dapat berujung pada konflik horizontal. Humaidy (2007) menyatakan bahwa perbedaan stratifikasi sosial menjadi penyebab konflik antar etnis. Pranata sosial dalam berbagai aspek akan menimbulkan gesekan sosial dan pandangan stereotype etnik yang rentan muncul benih-benih konflik bila dalam realitas sosial menampakkan sifat egois dan fanatisme yang nilai-nilai etnisitas. Benih-benih konflik bersifat laten, apalagi bila ditopang dengan harapan untuk menguasai dan mempertahankan powerprivilage-prestige. Disinilah timbul pergolakan sosial antara masyarakat "pribumi" dengan pendatang ataupun sesama etnis (Humaidy, 2007).

Selain konflik diatas, ada dua konflik yang tercatat dalam berbagai berita yaitu konflik FPI dengan Etnis Dayak tahun 2012 dan 2017. Tahun 2012 terjadi konflik antara FPi dengan Etnis Dayak yang disebabkan Perusakan papan nama asrama mahasiswa Pangsuma di Kota Pontianak diduga terjadi setelah sebuah spanduk 


\begin{tabular}{|c|c|c|c|c|}
\hline JURNAL & \multirow{2}{*}{ VOLUME 2 } & \multirow{2}{*}{ NOMOR 2 } & HALAMAN 86-92 & $\begin{array}{l}\text { ISSN 2655-8823 }(p) \\
\text { ISSN 2656-1786 }(e)\end{array}$ \\
\hline KOLABORASI RESOLUSI KONFLIK & H
\end{tabular}

bertuliskan penolakan terhadap Front Pembela Islam dipasang di dekat papan nama itu (Tempo, 2012). Pada tahun 2017 konflik kembali terjadi dipicu karena pengusiran oleh sekelompok orang di Bandara Supadio, Kalimantan Barat, terhadap pimpinan FPI Ahmad Sobri Lubis ketika akan menghadiri sebuah acara di Pontianak, Gubernur Cornelis juga berpidato kepada warga bahwa dia siap mengusir pemimpin FPI Rizieq Shihab jika mendatangi Kalimantan Barat. Aksi bela ulama berlangsung pada saat pembukaan Pekan Gawai Dayak yang sempat menimbulkan ketegangan antara kedua kelompok massa ( BBC Indonesia dan Tempo, 2017).

Konflik yang paling banyak terjadi di Kalimantan Barat adalah konflik antara Etnis Dayak dengan Madura. Menurut Bahari (2005) latar belakang terjadinya konflik, antara etnis Dayak dengan Madura adalah disebabkan oleh adanya aktor yang menggunakan isu SARA sebagai pemicunya (Arkanudin, 2006). Faktor penyebab lainnya adalah kesenjangan ekonomi, integrasi nasional yang lemah, pertentangan para elit, pertentangan primordial, ketidakadilan penyelenggaraan pemerintahan, ketidakadilan penerapan dan penegakan hukum, ketimpangan sosial dan sistem nilai dan orientasi budaya yang telah lama terpendam, prasangka sosial, etnosentrisme, dan stereotip negatif yang berkembang serta perilaku sosial menyimpangan dari etnik tertentu yang tidak dapat menyesuaikan dengan budaya dan adat istiadat masyarakat setempat (Arkanudin, 2006).

Puspa dan Prajarto (2008) mengungkapkan ada tiga belas stereotip Madura yang melekat di benak warga etnis Dayak dan Melayu, yaitu:

(1) senang berkelompok; (2) ikatan kekeluargaan yang kuat; (3) suka membawa senjata tajam; (4) kasar dan arogan; (5) agresif dan tidak tahu adat; (6) mudah tersinggung dan pendendam; (7) suka mencuri; (8) suka membunuh; (9) pengecut; (10) suka ingkar janji; (11) berpendidikan rendah; (12) ulet dan suka bekerja keras; dan (13) rajin menabung. Selanjutnya, prasangka terhadap Madura diekspresikan dalam berbagai wujud, yaitu: (1) antilokasi; (2) penghindaran; (3) diskriminasi; (4) serangan fisik; dan (5) pemusnahan.

Menurut Arkanudin (2006) bahwa perbedaan kondisi sosial budaya etnik Dayak dengan Madura antara lain berupa perbedaan pola dan lokasi pemukiman, pekerjaan, tingkat pendidikan, pelapisan sosial, kebiasaan dan stereotipe masyarakat pendatang dengan penduduk asli merupakan faktor yang dapat menjadi pemicu konflik contohnya adalah mudahnya kedua etnik (Dayak dan Madura) ini melakukan pertikaian disebabkan oleh dengan kebiasaan tradisional yang sering dilakukan oleh kedua etnis ini masih melekat sejak lama, yaitu kebiasaan mengayau pada etnik Dayak dan kebiasaan carok pada etnik Madura, yang mana secara fisik kebiasaan ini sudah jarang dilakukan, akan tetapi secara psikologis masih berpengaruh pada pola pikir masing-masing etnis.

Arkanudin (2006) mengidentifikasi faktor-faktor sosial budaya penyebab konflik tersebut sebagai berikut: 


\begin{tabular}{|c|c|c|c|c|}
\hline JURNAL & \multirow{2}{*}{ VOLUME 2 } & \multirow{2}{*}{ NOMOR 2 } & HALAMAN 86-92 & $\begin{array}{c}\text { ISSN 2655-8823 }(p) \\
\text { ISSN 2656-1786 }(e)\end{array}$ \\
KOLABORASI RESOLUSI KONFLIK & H
\end{tabular}

\begin{tabular}{|l|l|l|}
\hline IDENTIFIKASI FAKTOR & \multicolumn{1}{|c|}{ DAYAK } & \multicolumn{1}{c|}{ MADURA } \\
\hline Pola Pemukiman & Huma Betang & Tanean Lanjang \\
\hline Lokasi Pemukiman & Perdesaan & Perkotaan/Perdesaan \\
\hline Pekerjaan & Peladang,Peramu,PNS & $\begin{array}{l}\text { Pedagang, Buruh Kasar, dan } \\
\text { Petani }\end{array}$ \\
\hline Pendidikan & Rendah, Sedang, Tinggi & Rendah \\
\hline Pelapisan Sosial & Egaliter & Keagamaan dan kekayaan \\
\hline Kebiasaan & $\begin{array}{l}\text { Musyawarah, } \\
\text { Mengalah,Jujur }\end{array}$ & $\begin{array}{l}\text { Membawa senjata tajam, } \\
\text { solidaritas yang membabi } \\
\text { buta, ingkar janji }\end{array}$ \\
\hline Prasangka & $\begin{array}{l}\text { Pemalas, rawan dendam, } \\
\text { tidak matarialistis }\end{array}$ & $\begin{array}{l}\text { Pembuat onar, penyerobot } \\
\text { lahan, pelanggar hokum, } \\
\text { pendendam, preman }\end{array}$ \\
\hline
\end{tabular}

Sumber: Arkanudin (2006)

Dari berbagai macam konflik yang terjadi, sebenarnya bisa dipetakan dengan menggunakan segitiga SPK (Sikap, Perilaku, Konteks), terutama konflik yang berkaitan dengan identitas. Segitiga SPK merupakan suatu analisis berbagai faktor yang berkaitan dengan sikap, perilaku dan konteks dari pihak utama yang berkonflik (Fisher, 2000). Segitiga SPK ini bertujuan untuk mengidentifikasi ketiga faktor itu dan menghubungkannya dengan kebutuhan dan ketakutan masing-masing pihak yang berkonflik (Fisher, 2000). Hasil dari pemeteaan ini kemudian menjadi penentu awal intervensi yang akan diambil untuk penyelesaian konflik.

Berikut adalah contoh segitiga SPK konflik Dayak-Madura.

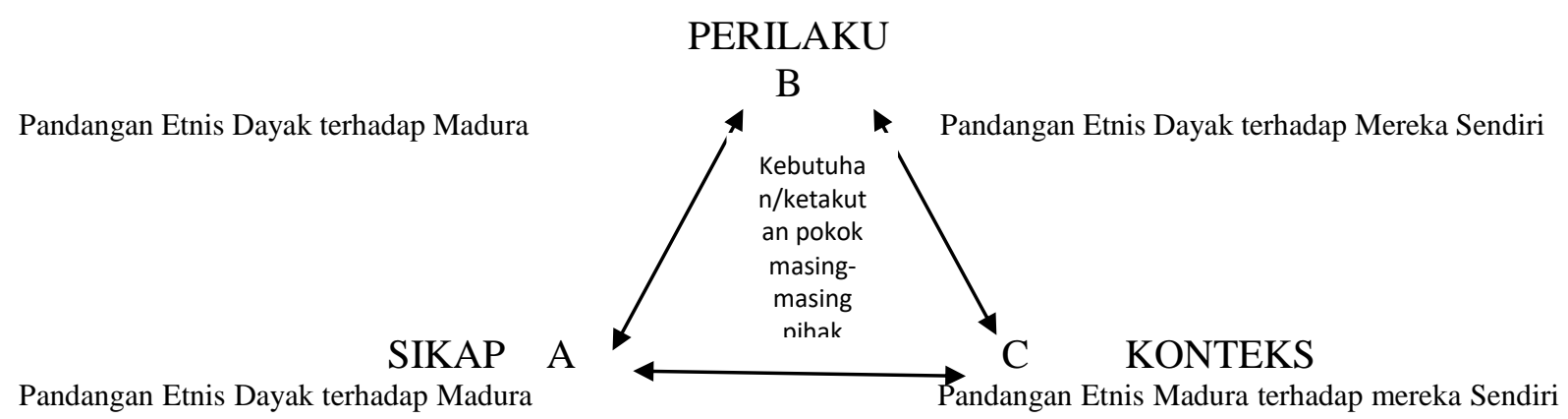

(diadopsi dari contoh Segitiga SPK Fisher, 2000)

Jika suatu saat terjadi pengulangan konflik, maka bisa menggunakan metode ini, yang mana bisa melihat seperti apa kekuatan identitas mereka mempengaruhi pemikiran mereka terhadap etnis lain, dan sebaliknya. Atau jika belum terjadi konflik, pengisian poin-poin dalam Segitiga SPK oleh antar etnis bisa menjadi evaluasi terhadap konflik sebelumnya ataupun prakiraan potensi konflik selanjutnya serta penyebabnya sehingga bisa dicegah atau diminimalisir potensi konflik tersebut. Jika kita melihat contoh segitiga SPK diatas, maka kita bisa lihat bagaimana "ke-identitas-an" Etnis Dayak digambarkan disegitiga tersebut dan bagaimana Etnis Dayak melihat Etnis Madura. Hal ini juga harus berlaku sebaliknya agar mendapatkan data yang akurat.

\section{KESIMPULAN}

Segitiga SPK bisa menjadi alternatif dalam pemetaan konflik yang terjadi di 


\begin{tabular}{|c|c|c|c|c|}
\hline JURNAL & \multirow{2}{*}{ VOLUME 2 } & \multirow{2}{*}{ NOMOR 2 } & HALAMAN 86-92 & $\begin{array}{c}\text { ISSN 2655-8823 }(p) \\
\text { ISSN 2656-1786 }(e)\end{array}$ \\
KOLABORASI RESOLUSI KONFLIK & H
\end{tabular}

Kalimantan Barat, yaitu konflik berbasis identitas etnis yang mendominasi sejarah konflik didaerah tersebut. Segitigas SPK bisa mengidentifikasi prasangka-prasangka dan ketakutan-ketakutan yang berkembang antar etnis, serta menggambarkan bagaimana identitas yang melekat pada masing-masing etnis mempengaruhi pola pikir dan pandangan terhadap etnis lain. Dari penggambaran-penggambaran tersebut selanjutnya bisa menjadi langkah awal untuk pengambilan intervensi penyelesaian konflik, prakiraan potensi konflik yang akan terjadi dimasa yang akan datang, ataupun sebagai upaya untuk meminimalisir terjadinya konflik dimasa depan dengan menyelesaikan prasangkaprasangka yang berkembang selama ini antar etnis yang pernah berkonflik, terutama konflik Etnis Dayak-Madura yang sering terjadi dalam sejarah konflik di Kalimantan Barat.

\section{DAFTAR PUSTAKA}

Alqadrie, S.I. (2008). Matahari akan Terbit di Barat. Pontianak:Yayasan Insan Cita Kalimantan Barat Anggota IKAPI

Arkanudin. (2006). Menelusuri Akar Konflik Antar Etnik Khusunya Dayak dengan Madura di Kalimantan Barat. Mediator Vol 7 No. 2 Desember 2006.

Creswell, J.W. 2012. Research design Pendekatan kualitatif, Kuantitatif dan Mixed; Cetakan ke-2, Yogyakarta: Pustaka Pelajar.

Fisher, S et all. (2000). Mengelola Konflik: Keterampilan dan Strategi untuk Bertindak. Jakarta: The British Council, Indonesia.

Haba, J. (2012). ETNISITAS, HUBUNGAN SOSIAL DAN KONFLIK DI KALIMANTAN
BARAT. Jurnal Masyarakat \& Budaya, Volume 14, No. 1

Humaidy, M.A. (2007). ANALISIS STRATIFIKASI SOSIAL SEBAGAI SUMBER KONFLIK ANTAR ETNIK DI KALIMANTAN BARAT. KARSA, Vol. XII No. 2

Kristianus. (2011). NASIONALISME ETNIK DI KALIMANTAN BARAT. Masyarakat Indonesia. EDISI XXXVII / NO.2 / 2011 | 147

Muhtifah, L. (2012). Model Penanganan Konflik Benuansa SARA di Kota Pontianak Kalimantan Barat. Juli September 2012 HARMONI

Puspa, D \& Prajarto, N. (2008). Strereotip dan prasangka dalam komunikasi antarbudaya: Studi komunikasi antarbudaya antar etnis Dayak dan Melayu terhadap etnis Madura di Singkawang Kalimantan Barat. NAGARA.

\section{Berita}

BBC Indonesia (2017). Aksi bela ulama di Kalbar 'tiru' politik SARA Pilkada Jakarta. $22 \quad$ Mei 2017 https://www.bbc.com/indonesia/indone sia-39992156 (24 Maret 2020)

Tempo. Co. (2017). Aksi Bela Ulama 205 Kisruh, Pontianak Berstatus Siaga. Sabtu, 20 Mei 2017 22:16 WIB https://nasional.tempo.co/read/877179/ aksi-bela-ulama-205-kisruh-pontianakberstatus-siaga/full\&view $=$ ok Maret 2020)

Tempo. Co. (2012). Kronologi Ricuh Spanduk Anti-FPI di Pontianak. Jumat, 16 Maret 2012 10:07 WIB https://nasional.tempo.co/read/390613/ kronologi-ricuh-spanduk-anti-fpi-dipontianak (24 Maret 2020). 